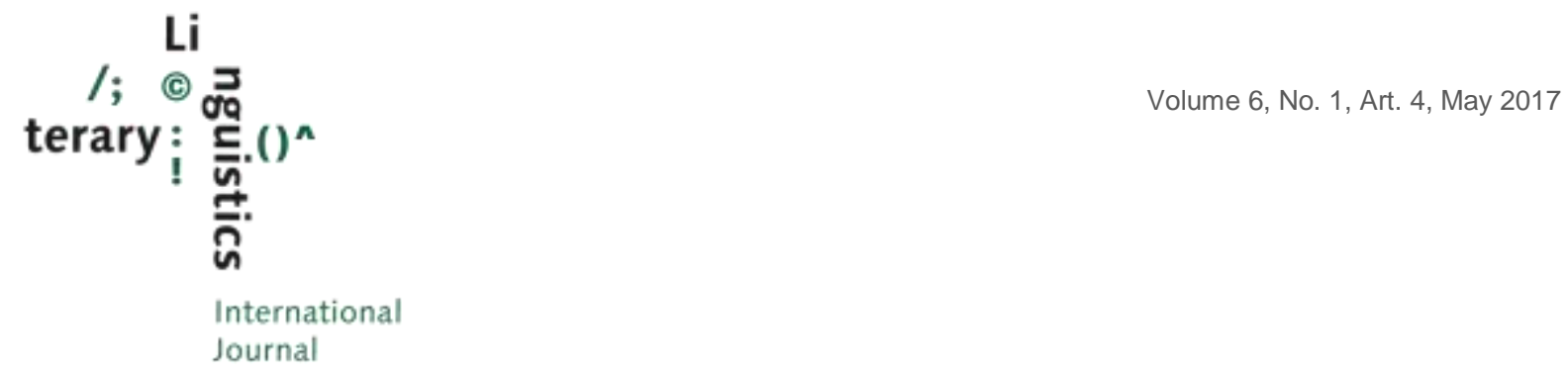

\title{
An Appraisal Theory Approach to Point of View in Mansfield Park and its Translations
}

Keywords:

Appraisal

Theory,

engagement,

dialogism,

verba dicendi,

epistemic

expressions,

stance, narrator

discourse,

direct speech, indirect speech, free indirect speech

\section{Victòria Alsina, Anna Espunya \& Maria Wirf Naro (Universitat Pompeu Fabra, Barcelona)}

Abstract: In order to achieve the goals of social commentary and moral judgement pursued in her novels, Jane Austen describes and evaluates different aspects of her characters' personalities: social attitude, intellectual qualities and moral traits (Lodge 1966). Mansfield Park (1814) is one of her novels in which this moral awareness is most acute. In order to construct a community of shared values with her readers, Austen skilfully alternates different points of view as sources of evaluation. We propose an analysis of the first chapter of Mansfield Park that addresses this dialogic dimension by focusing on the resources of engagement, the subsystem of Appraisal Theory with which speakers/writers express their commitment to the truth of a proposition and their willingness to open the negotiation space to other voices (Martin \& White 2005: 97).

The linguistic subtlety and complexity of Jane Austen's writing is a challenge to translators, who must try to identify all the concurrent interpretation possibilities and reproduce them in the target language. In this article we compare the English source text with various translations into Spanish, Catalan and German. Our analysis focuses on the lexicogrammatical realisations of engagement such as verba dicendi, epistemic expressions, lexical choices with a distinct attitudinal load, and also on the development of narration - as far as that is possible in a study centering on the first chapter -, since it is often the case that narrator stance is modified as the text unfolds.

We discuss fragments of narrator discourse, direct speech and indirect/free indirect speech and consider the advantages of the framework to uncover changes in the evaluative dimension of meaning that affect the readings the translations will afford in their target society, from character building to the articulation of points of view.

\section{Introduction ${ }^{1}$}

Jane Austen's mastery of narrative technique has drawn considerable attention from research in the fields of literary studies and of stylistics - or literary

\footnotetext{
${ }^{1}$ The research reported in this article has been funded by the Spanish government (MINECO), through project VALTRAD (FFI2013-42751-P). The authors belong to the research group CEDIT (2014 SGR 843). Authorship is shared on equal terms; authors appear in alphabetical order. We are grateful to the comments provided by the anonymous reviewers.
} 
stylistics, literary linguistics or linguistic stylistics, as it has also been called (Wales 2011: 400). Her narrative genius has proved an effective vehicle for, among other objects, evaluation, closely connected to her moralist side, which has been clear to her readers for a long time, at least since, in 1911, A. C. Bradley wrote: "There are two distinct strains in Jane Austen. She is a moralist and a humorist" (1911: 7, quoted in Stovel 1997: 233). Her novels, which on a superficial level can be seen as the heroine's search for the right husband, at a deeper level portray the characters' moral development towards a better knowledge of themselves and of those around them.

Mansfield Park (1814) is one of Austen's novels in which this moral awareness is most acute. Her evaluation of characters, of social groups or of their behaviour is presented to the reader in different ways: sometimes directly, through a narrator, who from an extra-diagetic position comments on and judges the qualities or actions described, often using irony; other times, also directly, through the words or thoughts of a reliable character; but most often it is done indirectly, through the characters' words and consciousness, to which the reader has access by means of a variety of constantly shifting speech and thought (and writing) presentation modes (Bal 1985, Cohn 1983, Leech \& Short 1981, Nünning 2001, Toolan 2001). This shifting between narrative modes makes it possible to subtly alternate the narrator's voice and/or point of view and those of various characters, thereby providing the reader with different perspectives from which to observe and evaluate.

We propose that the analysis of this alternation of voices and points of view as sources of evaluation can greatly benefit from an approach that takes intersubjective stance into consideration, namely Appraisal Theory, and particularly the semantic dimension of engagement (Martin \& White 2005: 97), i.e. the linguistic expression of commitment to the truth of a proposition and the willingness to open the negotiation space to other subjectivities.

Appraisal Theory has been applied primarily to non-fiction, particularly to texts with an argumentative function such as political speeches and various journalistic and academic genres. There is a growing interest in the application of the framework to the analysis of literary texts, including narrative fiction, as it opens new possibilities of interdisciplinary collaboration in modelling the role of the reader in textual interpretation. ${ }^{2}$

The linguistic subtlety and complexity in the articulation of points of view in Mansfield Park can be clearly appreciated by comparing translated versions of the work. Translation seldom consists in univocal and transparent word meaning transference determined by pre-existing relationships of equivalence such as can be found in bilingual dictionaries. Indeed, any act of translation requires first of all an attempt at textual interpretation. In literary translation, the translator

\footnotetext{
${ }^{2}$ Two current research lines are the combination of corpus techniques with the ontology of evaluation to identify the main literary themes of a work or an author (see, e.g., Miller \& Luporini 2015) and the exploration of the social semiotic mechanisms by which the literary work contributes to the construction of identity (see, e.g., Espunya \& Pavić Pintarić 2016).
} 
deals with the task of identifying all the concurrent interpretation possibilities and reproducing them in the target language, i.e. re-instantiating the original text in its whole potential (Farias da Souza 2013: 580). That may not always be possible: the solutions offered by the target language might be less multifaceted and oblige the translator to sacrifice certain contents in the translation; on the other hand, the closest available equivalent might at the same time imply further elements of meaning not detectable in the original. ${ }^{3}$

During translation, the evaluative dimension of the original discourse may be modified, which can affect the readings afforded by the new text in its target society (see, e.g., Hatim \& Mason 1990, 1997). In order to detect, analyse and describe translator interventions, the scholar needs a tertium comparationis. Appraisal Theory has already proved to be a promising framework in the work reported in Munday (2012).

In this article we analyse and compare translations of Mansfield Park into three languages, namely two into Castilian Spanish, both dated 1995, one into Catalan, dated 1990, and two into German, dated 1984 and 1989. The versions all belong to the same period, which ensures comparability of the historical and social contexts within each target society and between them. Multiple comparisons yield results that are relevant both for the literary translation scholar and for those not directly interested in translation, because taken together all the translations of a literary work reflect the range of interpretations (or dominant interpretations) the work has so far given rise to.

The structure of the paper is the following. Section 2 provides a brief introduction to Appraisal Theory, its assumptions and categories of analysis and their relevance for the study of narrative fiction. Section 3 provides a text analysis of several passages of the first chapter of Mansfield Park that illustrate the advantages of the framework for the study of engagement in the original text and its translations. We devote the final section to discussion and conclusions.

\section{A brief introduction to Appraisal Theory and its relation to concepts in narratology}

\subsection{Appraisal Theory as a model of stance-taking in writer-reader communication}

As anticipated in the introduction, our proposal is based on the assumption that it is possible, methodologically sound and beneficial to study literary texts with the analytical tools used initially for non-literary language. By considering a novel an act of communication, the focus is on how the writer seeks to engage with the reader even if they are separated by time and space. In his study of

\footnotetext{
${ }^{3}$ Translation has been defined as the intent to furnish for a certain text, produced in a given source language and rooted in a sociocultural and historic context, a corresponding piece in the target language: a reproduction which should be "equivalent for the occasion and purpose" (Yallop 2001: 231).
} 
dialogue in Jane Austen's novels, Babb (1962: 8) writes: "the style of an author is to be described in terms of the typical appeals that it makes, those signs that often suggest the writer's interpretation of the audience". Since Barthes' work (see, e.g., "The Death of the Author", 1967), the role of the reader has been recognised in literature and semiotics, as well as in translation and stylistics. For Leech and Short (1981: 257) "the writer has the goal of 'informing' the reader about a particular fictional world; but he also needs to achieve a rapport with his readers, an identity of viewpoint whereby the contents of the fiction will be interpreted and evaluated in an appropriate way". Significantly, recent approaches to the study of narrative deriving from the cognitive sciences, such as psychonarratology (see, e.g., Dixon \& Bortolussi 2001), have provided evidence that "readers process literary narratives in the same way as they do ordinary communication insofar as they assume a textually encoded conversational partner responsible for the contents of the narrative" (Margolin 2014: 2-3). The study of this interpersonal or intersubjective dimension requires adequate analytic tools. In the Cognitive Poetics framework, Stockwell (2013: 271) proposes the notion of a "deictic braid" as a tool for stylistic analysis of the reader's relationship to the characters, i.e. a bundle of deictic dimensions: perceptual, social, spatio-temporal and compositional/textual (adapted from Stockwell 2009: 127-131).

In this paper we explore the points of contact between Appraisal Theory (in particular the subsystem of engagement) and traditional narratological concepts such as narrator, point of view, etc. Appraisal Theory is a development within Systemic Functional Linguistics that concerns itself with the "subjective presence of writers/speakers in texts as they adopt stances towards both the material they present and those with whom they communicate" (Martin \& White 2005: 1). By communicating stance, the writer - understood as an addresser figure - construes for himself or herself a particular authorial identity. In narrative this addresser figure includes the narrator and possibly even one or more characters. The writer also tries to make his or her reader adopt a stance, and constructs for the text an intended or ideal audience that may be aligned or disaligned with his or her own views. Texts play a fundamental role in constructing communities of shared values, normative assessments, tastes and feelings.

The goal of Appraisal Theory is to model the dialogic effects of the meanings in three semantic regions: attitude (resources for construing emotional responses and value judgements, both ethical, i.e. on people's behaviour, and aesthetic, i.e. on the qualities of objects and phenomena, whether semiotic or natural), engagement (resources to adjust the speaker's commitment to his or her evaluations) and graduation (the resources to quantify, intensify and compare these evaluations). ${ }^{4}$ These semantic regions are instantiated by resources at all

\footnotetext{
${ }^{4}$ Each of the regions is conceived of as a subsystem of meanings. For instance, attitude is composed of three subsystems according to the domain being evaluated: affect (emotion), judgement (ethics) and appreciation (aesthetics). In turn, each of the subsystems is further developed into a semantic taxonomy. For example, judgement is subdivided into 'social esteem' (comprising 'normality', 'capacity' and 'tenacity') and 'social sanction' (comprising 'veracity' and 'propriety') (see Martin \& White 2005: 53). Engagement is presented in more detail in 2.2 .
} 
levels of the language system, i.e. lexicogrammar and phonology (Martin \& White 2005: 35, table 1.4).

Appraisal values can be positive, negative and ambivalent. Orientation, although linguistically marked in local terms, e.g. by the grammar of negation and by negatively oriented lexical items, is always context-dependent and it is finally the global interpretation of the text as a whole that determines it. Intratextual relations can shift orientation; hence the rhetorical structure of the text is as important as the resources deployed at sentence-level.

When texts contain declarations of attitude, these are "dialogically directed towards aligning the addressee into a community of shared value and belief" (Martin \& White 2005: 95). The term 'align'/'alignment' refers to agreement not only with the attitudinal assessment but also with the "beliefs or assumptions about the nature of the world, its past history, and the way it ought to be". This is relevant for an analysis of Mansfield Park because in this work Jane Austen challenges precisely those beliefs and assumptions by placing inscriptions of attitude in voices external to that of the narrator.

Appraisal Theory originated in studies of literacy development in Australia, and has been further applied to the ideological analysis of texts belonging to genres with argumentative goals: journalistic (see, e.g., Bednarek 2006), academic (see, e.g., Hood 2010) and political speeches (see, e.g., Munday 2012). The main difference between these genres and prose fiction lies in the sender figure. While the reader assumes that the authorial identities of journalists, academics or politicians reflect their own values, this is not necessarily so with the writer of fiction. A work of fiction may be analysed as instantiating several types of sender at different levels of embedding (Leech \& Short 1981: 262-272): author, narrator, implied author and implied narrator (terminology from Booth 1961). Usually, author and implied author are conflated. The embedding of voices is modelled in Peng (2008) as an embedding of communicative contexts, most notably the authorial context embedding the narrator context.

The addressee in literary communication is the I-reader, or implied reader, "a hypothetical personage who shares with the author not just background knowledge but also a set of presuppositions, sympathies and standards of what is pleasant and unpleasant, good and bad, right and wrong" (Leech \& Short 1981: 259).

In the case of Mansfield Park, published in 1814, the original implied reader was a contemporary of Jane Austen. The novel would thus have construed a community of shared values and emotions that its readers could be aligned or disaligned with. In Poovey's words (1997: 95):

Austen's graphic depiction of the moral deterioration within the landed gentry suggests her growing awareness that she might need to create a family of readers with a common set of values instead of merely assuming that such readers already existed. 
The modern reader is not the original implied reader; hence he or she will have to allow for social changes that have taken place and, for example, refrain from judging Fanny Price as lacking credibility as a character (see Leech \& Short 1981: 260).

The subsystem of Appraisal Theory that is relevant for the analysis of resources for alignment and disalignment between reader and writer is engagement. The following section provides a brief introduction.

\subsection{Engagement in Appraisal Theory}

The higher-level distinction made in the subsystem of engagement is that between monoglossic and heteroglossic statements, which is based on whether they recognise dialogic alternatives. Monoglossic statements present propositions as taken for granted, not at issue. Typical linguistic realisations are presuppositions and categorical bare assertions. Heteroglossic statements present propositions as not taken for granted. Typical linguistic realisations are related to the systems of modality and evidentiality and include modal verbs and modal adjuncts (mainly with epistemic meaning) and verbs of reporting. Nevertheless, specific linguistic realisations are only cues to dialogic positioning, as it in fact depends on several factors: the communicative objectives being pursued by the text as a whole, the proposition's role with respect to those objectives and the nature of the proposition itself (i.e. evaluative or emotive contents vs. experiential) (see Martin \& White 2005: 100).

Within heteroglossic positioning, a distinction must be made between 'dialogic contraction', the formulation of propositions in a way that "close[s] down the space for dialogic alternatives" (Martin \& White 2005: 103) and "dialogic expansion', in which propositions "open up" that space so that alternative positions may be formulated at a small interpersonal cost. Contraction can occur in two varieties: 'disclaim' (a dialogic alternative is rejected, presented as not applying or supplanted by another) and 'proclaim' (formulations acting to limit the scope of dialogic alternatives). 'Concur', 'endorse' and 'pronounce' are three subtypes of proclamation. When concurring, the addresser is overtly announced as agreeing with or having the same knowledge as some projected dialogic partner. In endorsement, propositions which are sourced to an external subjectivity are construed by the authorial voice as correct; in pronouncing, it is the authorial voice itself that is construed as correct, either implicitly or explicitly. Expansion may involve 'entertaining' a position (the proposition is grounded in the individual internal subjectivity of the speaker/writer) or 'attributing' it (the proposition is grounded in an external subjectivity). In turn, attribution may have a distancing orientation (the author explicitly declines to take responsibility for the proposition) or an acknowledging orientation (the authorial voice does not specify its position with respect to a proposition). 


\subsection{Engagement and speech and thought presentation modes}

Considering the narrator and the characters as figures for whom the reader construes points of view or perspectives (see Nünning 2001), ${ }^{5}$ each of these subjectivities can have its own communicative objectives and hence has the potential to proffer monoglossic and heteroglossic statements in the form of speech and thought, as well as writing, which, albeit not so frequent, can also be found in Jane Austen's works in the form of letter-writing. Reported discourse ${ }^{6}$ has traditionally been divided into direct speech and thought, reported or indirect speech and thought and free indirect speech and thought, to which narrative report of speech acts has been added more recently (Leech \& Short 1981). ${ }^{7}$ These three conventional labels (direct, indirect and free indirect) in fact cover a much wider variety of finely graded forms ranging from total narrator control to no narrator control at all, so that, as McHale (2014: 2-3) states:

In view of the range and diversity of each of these forms, especially ID and FID [indirect discourse and free indirect discourse], and the evidence of intermediate or ambiguous instances, some analysts have concluded that a scale of possibilities would be more adequate than the three-category model (McHale 1978; Leech \& Short 1981).

He goes on to observe, however, that these scalar models are equally unable to capture the "diffuse and transient effects of "voice"' found regularly in narratives.

To these objections a new one has been added: since the 1990s cognitive narratologists have challenged the application of the "speech-category approach" to thought presentation, as in effect it "limits consciousness in fiction to varieties of inner speech" (McHale 2014: 8). Other stylisticians, however, argue for the continuing usefulness of the traditional categories (Bray 2014: 222). While we are aware of the drawbacks presented by any classification of a complex and finely nuanced reality, we think that the existing categories are useful, especially as it is mostly thought presentation that has come under criticism, and we are mainly - although not only - interested in speech presentation.

These categories are orthogonal to categories of engagement. That is, given any sentence in a narration, its formal (syntactic) presentation mode does not predict the category within the subsystem of engagement. The application of Appraisal Theory requires the analyst to observe how the "authorial voice is positioning itself with respect to the anticipated reactions and responses of the audience which is being construed for the text" (Martin \& White 2005: 135). In

\footnotetext{
${ }^{5}$ We understand the terms 'perspective' and 'point of view' as referring to equivalent notions proposed in different academic traditions. In this we follow, for example, Niederhoff (2013).

${ }^{6}$ As distinct from narrator discourse, named narrative report of action by Leech and Short (1981: 324).

${ }^{7}$ To speech and thought presentation, writing presentation has been added by Leech and Short (2007: 303) in the second edition of Leech and Short (1981).
} 
the following section we analyse relevant instances of engagement moves in Mansfield Park in order to throw new light on the narrative technique of Jane Austen that allows her to build her community of values with her readership.

\section{Engagement in Mansfield Park}

In what follows we illustrate different dialogic possibilities in narrator discourse and in different speech and thought presentation modes. We have a double aim: on the one hand, to analyse the text in its original version, and on the other, to provide a comparative analysis of several translations, to observe the shifts that may occur as a consequence of the text's re-instantiation with the resources of the target language and the translators' intervening subjectivity. ${ }^{8}$

We will examine narrator discourse, direct speech and indirect and free indirect speech separately. In 3.1 we discuss narrator discourse, in which the narrator is the main responsible source of engagement; this includes both narrative report of action and narrative report of speech acts, in Leech and Short's terminology. In 3.2 we will examine instances of direct speech, in which the narrator acknowledges other voices; dialogue takes place between the characters, and dialogic engagement takes place between characters but also between characters and the reader. In 3.3 we examine instances of indirect and free indirect speech, in which dialogue takes place between the characters with the mediation of the narrator so that it is often difficult to differentiate the source of engagement (i.e. the narrator or a character).

\subsection{Narrator discourse}

Mansfield Park is related by a third-person extra-diegetic narrator, the most authoritative figure in written fiction (Morini 2010: 344); "the values [this narrator] propounds provide a normative standard according to which all the characterperspectives are judged" (Nünning 2001: 219). According to Babb (1962: 159), in Mansfield Park Jane Austen makes her "nearest approach to the convention of the omniscient author".

The points of view put forth in Mansfield Park are clearly complementary and converge in a single normative worldview, giving the novel a monologic structure in Bakhtinian terms (Nünning 2001: 217). The narrator is apparently omniscient, recounting events, judging characters and attributing propositions to the characters (engaging in what Morini (2010: 346) calls ventriloquism); for the latter function, Austen makes her narrator use an expansive engagement mode,

\footnotetext{
${ }^{8}$ The notation used in the discussion is the following: ST = Source Text; T1 ... T5 = Target Text 1 ... Target Text 5, in the set order Spanish (1) and (2), Catalan (3), German (4) and (5). We do not offer complete back translations of the non-English texts because the relevant fragments are translated or glossed as part of the analysis.
} 
mostly restricting herself to acknowledging the different voices. ${ }^{9}$ In the first chapter, devoted to family history leading to Fanny's adoption, verbal behaviour of characters is reported very extensively by the narrator. The syntactic pattern used in this reporting is 'third person singular subject + verbum dicend', as illustrated by the fragments in (1). Nevertheless, the appearance of neutrality is deceptive because the narrator's reports of speech acts include elements that may cause a distancing effect, mainly by overspecifying emotional or epistemic aspects of the speech acts being reported. The most relevant categories are references to the manner of speaking (loudness, emphasis, tone, affect), the frequency with which a topic is discussed and the degrees of probability. These linguistic realisations appear in bold type in (1).

(1) a. All Huntingdon exclaimed on the greatness of the match [...]. (Austen 1) [affective reaction]

b. her uncle, the lawyer, himself, allowed [...]. (Austen 1) [excessive crediting, plus focus]

C. such of their acquaintance [...] did not scruple to predict [...]. (Austen 1) [force]

d. [...] that Mrs. Norris should tell them, as she now and then did in an angry voice, that [...]. (Austen 2) [affective reaction]

e. Mrs. Norris was often observing to the others, that she could not get her poor sister and her family out of her head [...]. (Austen 3) [progressive aspect expressing insistence]

f. [...] her views were more fully explained [...]. (Austen 6) [focus with graduation]

g. [...] said Lady Bertram with the utmost composure. (Austen 7) [affect with graduation]

h. Sir Thomas added with dignity [...]. (Austen 7) [affect]

The changes in stance (such as neutrality vs. distance, and positive vs. negative orientation) with respect to the values that help build a community with her readers occur not only within a sentence but intersententially, as the text unfolds. We try to illustrate this by analysing the first paragraph in detail.

The first sentence in the opening chapter of Mansfield Park provides an instance of an apparently monoglossic - or highly contractive - discourse:

(2) About thirty years ago Miss Maria Ward of Huntingdon, with only seven thousand pounds, had the good luck to captivate Sir Thomas Bertram, of Mansfield Park, in the county of Northampton, and to be thereby raised to the rank of a baronet's lady, with all the comforts and consequences of an handsome house and large income. (Austen 1)

\footnotetext{
${ }^{9}$ Throughout the article the narrator figure of Mansfield Park is referred to in the feminine gender, except in citations from other works, in which case the original gender choice is respected, or when referring to the role of the narrator in general.
} 
The sentence contains two logically connected clauses, each of them proffering a seemingly unproblematic assertion, at first without referring explicitly to other external voices or viewpoints. The statement is presented as if the narrator expected readers to agree with several assumptions contained in it. These assumptions are the following: in the first place, that marrying a baronet, rising in rank and becoming rich must necessarily be viewed in a positive light. Also, perhaps less foregrounded, that a woman's wealth determines the rank and wealth of the husband she should expect. Finally, that obtaining a 'better' husband than one's wealth 'entitles' one to can only be attributed to luck ("Miss Maria Ward [...] with only seven thousand pounds, had the good luck to captivate Sir Thomas Bertram"). In the latter assumption, as in the first set of assumptions, the narrator is building on a community of shared values with her contemporaries; she is basing her statement on what may be considered the opinion sanctioned by society ('society' being represented by "All Huntingdon" in the sentence that follows). The construal of the match as a lucky event invokes the immutability of the social practices and principles held by at least part of the society of the late 18th century. The reader is offered an interpretation of the facts to align or disalign with.

The initial reading of this seemingly straightforward opening is soon altered. The assumptions and the preconceptions they are based on (about what kind of person is entitled to a good husband - and to a good wife - and what makes a good spouse) are first undermined in the sentence immediately following it (discussed below), and ultimately completely turned around by the events narrated in the course of the novel. By the end, the ideas and principles which the narrator initially seemed to be presenting as unquestionable have been proved not so sound. Using the narrative and linguistic means explained in this section, the narrator contributes to the further construction, refinement, and even modification, of the community of shared values she started with.

In the sentence immediately following the opening pronouncement, the narrator appears to be adding support to her previous assertion in the form of two voices reinforcing it:

(3) All Huntingdon exclaimed on the greatness of the match, and her uncle, the lawyer, himself, allowed her to be at least three thousand pounds short of any equitable claim to it. (Austen 1)

The first voice is that of "all Huntingdon" - that is to say, society, or rather, Miss Maria Ward's society -, which is inserted by the narrator to provide a judgement on the match ("greatness"), presented as the complement of exclaim on. This verb denotes the verbal manifestation of surprise - hence an affective response - at something, together with either approval or disapproval. ${ }^{10}$ The greatness of

\footnotetext{
${ }^{10}$ Whether the surprise is mixed with approval or disapproval depends on the context. The $18^{\text {th }}$ and $19^{\text {th }}$-century examples of exclaim on found in the OED online convey complaint rather than admiration. On the other hand, it seems natural, given the context, to read admiration into "all Huntingdon['s]" exclamations, although the possibility is left open that there may also be something of censure or envy in them. Whether the sentence is to be interpreted as expressing a
} 
the match, by being presented as the verb complement, is encoded as a presupposition, hence taken for granted, not open to debate from the point of view of Miss Maria's circle: we are never told how the match was considered from the point of view of Sir Thomas's family and neighbours, but it seems natural to infer that if the marriage was advantageous for her, it may have been disadvantageous for him. At the level of the narrator, we need to distinguish different stances (support, reject or neutral).

The next voice introduced, that of Miss Maria's uncle, the lawyer, is acknowledged to concede - using legal terms - that the match is both advantageous and unexpectedly so; this concession is conveyed by means of the verb allowed, which expresses acceptance of the judgement voiced by society. Because the narrator acknowledges the propositions of the external voices, and does not commit herself to their truth, it could also be understood that although apparently adding support to her previous assertion, she is in fact subtly distancing herself from it by indicating that the so-called greatness consists solely in monetary gain. The choice of values that are made explicit is part of the argumentation in Mansfield Park.

It is interesting to analyse the translated versions to observe the rendering of acknowledgement of propositions in this sentence. We focus on the translation of exclaim on as a good example of semantic richness (verbal response, affect and orientation) that needs to be rendered.

(4) T1 Todo Huntingdon se hizo lenguas de lo magníficamente bien que se casaba, y hasta su propio tío, el abogado, admitió que ella se encontraba en inferioridad por una diferencia de tres mil libras cuando menos, en relación con toda niña casadera que pudiera justamente aspirar a un partido como aquél. (Martín 9)

T2 Todo Huntingdon proclamó la grandeza del partido, y su propio tío el abogado reconoció que le faltaban tres mil libras al menos para tener justo derecho a él. (Torres 7)

T3 Tot Huntingdon va proclamar la magnificència del casament i el seu mateix oncle, l'advocat, va manifestar que ella estava almenys tres mil lliures per sota de qualsevol altra candidata. (Ventós 9)

T4 Ganz Huntingdon wusste sich über diese großartige Partie nicht zu lassen, und sogar ihr eigener Onkel, der Rechtsanwalt, gab zu, dass ihr mindestens 3000 Pfund fehlten, um solche Ansprüche stellen zu können. (Grawe \& Grawe 5)

T5 Ganz Huntingdon ereiferte sich über diese reiche Heirat, und ihr Onkel, der Rechtsanwalt, meinte, sie hätte eigentlich mindestens 3000 Pfund mehr mitbringen müssen, um darauf einen vertretbaren Anspruch zu haben. (Meyer 5) 
The Spanish colloquial idiom hacerse lenguas de algo in T1 means 'to praise emphatically'. The givenness of the quality under consideration is maintained in this expression, but not the surprise expressed by exclaim on, nor its ambivalence, as hacerse lenguas de is decidedly admiring; the intensification infused in exclaim is also reflected by the paraphrase lo magnificamente bien, which has exclamatory value ('how wonderfully well she was marrying'), and the lexical intensification in magníficamente (literally, 'wonderfully well').

The choice of proclamar in T2 (closer to proclaim than to exclaim) eliminates the projection of surprise as the reaction to the news, and as an instance of the proclaim category, does not commit the orientation of the speaker. The object is changed, as the greatness is attributed not to the match but rather to the man as an eligible partner (the colloquial idiom ser alguien un buen partido means 'to be someone who is single, ready to marry and with good standing').

In the Catalan translation (T3) the choice is also proclamar, with the same shift in meaning as we have seen in T2. But in this case the object is, as in English, the match (casament, 'marriage'), which can be interpreted as a positive judgement on Miss Maria's capacity or positive appreciation (valuation) of the action. There is also a difference in graduation from greatness to magnificència, which is closer to the positive pole than the source text, perhaps making up for the loss in infused intensification caused by the choice of proclamar, although the target of appraisal differs.

In the first German translation (T4), sich nicht zu lassen wissen - 'sich nicht fassen, beruhigen können' ('to be unable to calm down'), according to Digitales Wörterbuch der deutschen Sprache - conveys the idea of a strong emotional response which might also imply a positive evaluation and contains an element of duration which the original does not convey. "Diese großartige Partie" corresponds in effusiveness and polysemy - Partie denoting both (the possibility of) marriage and the person to be married - to "the greatness of the match". The demonstrative and the less nominal formulation even add a slight ring of orality: this acknowledgement might reproduce a piece of what was actually said.

In the second German translation (T5), sich ereifern means 'speaking heatedly', in order to defend a position, according to the definition of Duden online; in the examples of use given by Digitales Wörterbuch der deutschen Sprache, this reaction mostly concerns something evaluated as negative. The ambivalence in orientation of the original exclaim is hence reproduced, though not the seme of surprise. "Reiche Heirat" puts the object of emotion even somewhat more crudely than the source text, retaining only the financial aspect of the act of marriage. Given the context, this is certainly in line with the general feeling, but Huntingdon appears more bluntly materialistic in its reactions than in the other translations.

To recapitulate, all five translations maintain the narrator's ventriloquism - and resulting irony - in presenting us the "assumption of a 'Huntingdon point of view'" (Morini 2010: 346); but each translator provides a slightly different rendering of exclaim on, none of them including the narrator's projection of 
surprise, which is crucial for the dialogic expansiveness of the narrator's perspective, and only T4 and T5 including the ambivalence of 'exclaimed'.

As far as the object "greatness of the match" is concerned, in three translations, namely T1, T3 and T4, greatness is rendered by a word denoting a higher degree on the scale.

Shifts in translation such as those illustrated above clearly alter the evaluative potential of the narrator's voice. They can also deny the reader access to touches of humour with which the narrator sprinkles her story, as in the following excerpt. In the preceding discourse, Mrs. Norris has succeeded in convincing her brother-in-law to adopt one of her nieces, Fanny Price, the nine-year-old daughter of her youngest sister, and has even proposed an economical arrangement to bring the girl to Mansfield Park by having her stop over at a cousin's of the housekeeper Nanny.

(5) ST Except to the attack on Nanny's cousin, Sir Thomas no longer made any objection, and a more respectable, though less economical rendezvous being accordingly substituted, every thing was considered as settled [...]. (Austen 6)

T1 Excepto la impugnación del plan en la parte en que se hacía intervenir al primo de Nanny, sir Thomas no opuso más objeciones, y una vez sustituido el punto de reunión por otro más respetable, aunque no tan económico, se consideró que todo estaba arreglado. (Martín 13)

T2 Salvo su rechazo al primo de la niñera, sir Thomas no puso ya ninguna objeción; y tras sustituir ese lugar de encuentro por otro más digno, aunque menos económico, se consideró todo arreglado. (Torres 12)

T3 Llevat de l'oposició al cosí de la Nanny, Sir Thomas no va fer cap més objecció. Es va deliberar i decidir un lloc d'encontre més respectable, però menys econòmic, i tothom va gaudir de bell antuvi de la satisfacció d'aquesta idea tan bondadosa. (Ventós 12)

T4 Außer gegen den Überfall auf Nannys Vetter erhob Sir Thomas keine weiteren Einwände; und als man sich dementsprechend für einen respektableren, wenn auch weniger preisgünstigen Treffpunkt entschieden hatte, galt die Sache als abgemacht, und [...] (Grawe \& Grawe 11)

T5 Mit Ausnahme des Überfalls auf Nannys Cousin erhob Sir Thomas keine Einwände mehr, und da ein standesgemäßerer, wenn auch weniger kostengünstiger Treffpunkt an dessen Stelle trat, wurde alles als abgemacht betrachtet, und [...] (Meyer 11)

In the source text, the word attack ironically recasts the involvement of Nanny's cousin as a form of aggression by Mrs. Norris. This may trigger the reader's need to attribute the irony in the statement to a voice. There are at least two candidates, namely the narrator and the subject of the main clause, Sir Thomas. In the first Spanish translation, the word attack is paraphrased by a mocking legal description ("the challenge to the plan in the part where the cousin's involvement was foreseen"). Irony is effaced, even though it is compensated by the humorous parody of legalese (note the word impugnación). The second 
Spanish translation changes the object of the evaluation from Mrs. Norris's plan to the cousin himself. Obviously, the item rechazo ('rejection') is less awkward because it denotes the lowest degree on a scale of aggression. However, the preferred interpretation of attack is not a rejection of the cousin but a rejection of the plan to use his house as a meeting point. The translator has toned down the force of attack (which is a hyperbole), probably enhancing the smoothness of the reading experience while removing the potential for a humorous effect. This toning down, referred to as 'neutralisation' in Translation Studies, involves the removal of an unusual feature of the text such as metaphor and irony (see, e.g., Øverås 1998) as well as the substitution of choices with the potential to upset readers' sense of propriety (taboo, offensive language, explicit depictions of brutality, reduction of interpersonal distance, etc.). One can speculate that the translator did not grasp the figurative sense in which Mrs. Norris intended to 'attack' Nanny's cousin and found the word too blunt. The Catalan translation, which uses the term oposició, 'opposition', is in line with the second Spanish translation in interpreting that Sir Thomas has some objection to the cousin and not to the plan to use his house; the irony is therefore also lost in this version. The comment made to T2 is applicable here as well. In contrast, the German translations preserve the irony with an equivalent rendering of attack. Überfall is perhaps slightly smoother in so far as the word embraces a humorous, colloquial acceptation of 'surprising visit'. Since relaxed forms of speaking are not really in line with Sir Thomas's stern dignity, we are inclined to interpret these phrasings as part of the narrator's side-swipes at Mrs. Norris and her aggressive activity.

In the first chapter argumentation plays an important role, as the events being related are also presented as the grounds for what finally happens at Mansfield Park. The narrator occasionally gives hints of engagement through epistemic elements, for example certainly and indeed. Their semantic and pragmatic multidimensionality and their role in the characterisation of a speaker can be difficult to render in translation. Consider the following example, where the narrator is comparing Miss Ward's marriage with Frances Ward's fate.

(6) ST Miss Ward's match, indeed, when it came to the point, was not contemptible [...]. (Austen 1)

T1 El enlace de miss Ward, llegado el caso, no puede decirse que fuera tan despreciable (Martín 9)

T2 En realidad, el matrimonio de la señorita Ward, llegado el momento, no resultó desdeñable [...]. (Torres 7)

T3 Tot i amb això, a l'hora de la veritat, el casament de la senyoreta Ward no va ser tan desafortunat [...]. (Ventós 9)

T4 Ja, Miss Wards Verbindung erwies sich, als es soweit war, als durchaus nicht zu verachten [...]. (Grawe \& Grawe 5)

T5 Miss Wards Heirat war im Grunde genommen nicht zu verachten [...]. (Meyer 5)

In the source text the speaker expresses a high degree of certainty, "not to indicate something about his or her knowledge but to insist upon his/her point of 
view when it [...] is in contrast with a preceding proposal or assumption" (Aijmer 2007: 335). To put it in Martin and White's terms, it is a piece of contractive dialogue: the narrator proclaims and more specifically pronounces a statement and at the same time disclaims - counters, to be exact - the previous supposition (that being married to a man "with scarcely any private fortune" is bad). In the original, then, the narrator makes a decided appearance; the different translations slightly vary in part.

The first Spanish translation gives the intervention of the narrator a different shade. Disclaiming the view that the match was 'so contemptible' instead of affirming it was 'not contemptible', this narrator is less decidedly positive in her appreciation, but her appearance as an entity outside the plot becomes more apparent through the present tense (no puede decirse - 'it cannot be said') which breaks alignment with the hic et nunc of the novel space and the ring of orality and improvisation given by the syntactic segmentation ("El enlace de miss Ward, $[\ldots]$ no puede decirse que fuera [...]").

The second Spanish, the Catalan and the second German translations retain particularly the disclaiming element of indeed: the initial impression is countered, but the "not contemptible" quality of Mr. Norris's situation is affirmed less strongly (especially in T3, with the negation of the graduating element ("no [...] tan desafortunat" - 'not so unfortunate'). The translation by Grawe and Grawe is the most affirmative one: sich erweisen als claims definite truth value; durchaus adds a graduative; the initial Ja, segmented and with the following pause, highlights the pronouncement quality. And as the perception of the discourse marker merges easily with that of the answer particle, it adds a touch of conversational presence to the picture we form of this narrator.

The certainly a few lines earlier situates her in the same vein:

(7) ST But there certainly are not as many men of large fortune in the world, as there are pretty women to deserve them. (Austen 1)

T1 Pero en el mundo no existen ciertamente tantos hombres de gran fortuna como lindas mujeres que los merezcan. (Martín 9)

T2 Pero lo cierto es que no hay tantos hombres acaudalados en el mundo como mujeres bonitas dignas de ellos. (Torres 7)

T3 Però la veritat és que no hi ha tants homes de fortuna considerable al món com dones boniques que se'ls mereixen (Ventós 9)

T4 Aber natürlich gibt es auf der Welt nicht so viele Männer mit ansehnlichem Vermögen, wie es hübsche Frauen gibt, die sie verdienen. (Grawe \& Grawe 5)

T5 Aber sicher gibt es nicht so viele Männer mit einem ansehnlichen Vermögen auf der Welt wie hübsche Frauen, die sie verdienen. (Meyer 5)

In the source text the narrator proclaims the statement but hedges it through the use of certainly: although the adverb itself is contractive, it renders the sentence less categorical than a bare generalisation "there are not so many men [...] as pretty women to deserve them". It may then be interpreted as the narrator's 
willingness to entertain (in the sense of Martin \& White 2005: 98) alternative views. Assuming that the proportion of wealthy men and "pretty women to deserve them" is not a balanced one implies the presupposition that the second group can be delimited. The infinitive construction even admits two basically differing definitions of this group: if it refers to 'pretty women, who deserve them', prettiness becomes a sufficient condition; if interpreted as 'pretty women who deserve them', further qualities would be necessary to be eligible as a wealthy man's spouse. The chapter opening affords the reading that at least part of Huntingdon does not regard beauty alone as merit enough. When the narrator shows herself inclined towards the estimation that there are more women in the world, who would, for all kinds of reasons, deserve a rich husband, than available 'matches', she offers the reader an opportunity for alignment or disalignment - with the estimation and its underlying implications in the first place.

German cannot reproduce the infinitive construction, but as the comma in front of subordinate clauses is obligatory, the translation by a relative clause remains just as ambiguous as the original. The natürlich in Grawe and Grawe's translation concurs: the narrator agrees with the "projected dialogic partner", "the text's putative addressee" (Martin \& White 2005: 122), i.e. the reader preventing him/ her at the same time from taking an alternative standpoint. Sicher and ciertamente are dialogically more expansive, entertaining a position and leaving space for divergence. They, too, establish contact between the narrator and the reader.

When rendering the infinitive by a relative clause, Spanish and Catalan punctuation oblige the reader to choose between defining and non defining relative clause. T1 (Martín) and T3 (Ventós) opt for a defining one and T2 (Torres) for the distinctive use of an adjective in postnominal position so that the original ambiguity is lost in favour of 'prettiness and more qualities'. Lo cierto es que and la veritat és que are epistemically equivalent to certainly. However, they embed the statement under discussion as a subordinate clause, while the main clause is reserved to the positioning of the speaker; they foreground the engagement of the narrator far more strongly than the three-syllable adverb certainly.

Obviously, the structural difference between languages sometimes makes oneto-one equivalents in a particular text passage of translation impossible. That the ambiguity of the original's infinitive construction must be lost in Spanish and Catalan is no problem on the information level: it is 'only' an early hint that prepares the questioning of Huntingdon's values which runs through the whole novel. But it slightly alters our image of the narrator, and the translation of an unobtrusive adverb like certainly even makes a notable difference in the presentation of the narrator as more or less omniscient and self-confident in her affirmations. 


\subsection{Direct speech}

Direct speech is attribution at the basic level of narrative structure: the narrator attributes the proposition to an external subjectivity by inserting an utterance constructed as if it came unmediated from its source. By default, i.e. unless the authorial voice of the narrator appears in the inquit in order to distance itself from the contents, direct speech is acknowledgement of the proposition in Martin and White's sense.

An important resource for characterisation is the characters' dialogic disposition, i.e. their readiness to engage in reasoning and argumentation and to negotiate positions (see, e.g., Babb 1962: 156-159). In the first chapter Mrs. Norris's preferred mode of communication is contractive, while Sir Thomas's is expansive. When objections are raised to the adoption of one of Frances Price's daughters, Mrs. Norris counters them with a flow of speech intended to win Sir Thomas over to the cause (Austen 4-5). There is little expansiveness in her use of language, as attested by the following choices: imperatives ("Do not let us be frightened from a good deed by a trifle."), the conditional imperative construction ("Give a girl an education, and introduce her properly into the world, and ten to one but she has the means of settling well [...]"), categorical statements (the noun trifle to refer to the moral and financial objections, "It is morally impossible"), hedged expressions of modal certainty such as "I dare say", and expressions of probability graduated to the lowest extreme ("the least likely", "she will never be") or highest ("ten to one").

The debate around the adoption of Fanny Price is a particularly relevant one in Mansfield Park, as all the quasi-certainties expressed by Mrs. Norris will be proved wrong by the course of events.

Sir Thomas, who is the head of the family, is remarkably expansive in his expression, as illustrated in the next example, which is followed by the Catalan translation. Sir Thomas, about to adopt Fanny Price, worries about her disposition and the influence she might have on his children.

(8) ST 'Should her disposition be really bad,' said Sir Thomas, 'we must not, for our own children's sake, continue her in the family; but there is no reason to expect so great an evil. We shall probably see much to wish altered in her, and must prepare ourselves for gross ignorance, some meanness of opinions, and very distressing vulgarity of manner [...].' (Austen 8)

T3 Si resulta una criatura de mala mena - va dir Sir Thomas -, pel bé dels meus fills, no permetré que continuï entre nosaltres; però no cal que pensem en un mal tan gran. Segurament li trobarem molts defectes i ens haurem de preparar per suportar una gran ignorància, una falta de criteri $\mathrm{i}$ unes maneres penosament vulgars [...]. (Ventós 13)

His words, forming a markedly expansive discourse (as opposed to that of Mrs. Norris), are acknowledged by the narrator by means of direct speech; in contrast to his situation of authority as head of the family in a patriarchal society, this character uses a great number of linguistic resources which allow for 
alternatives, most notably the use of the modal of obligation must with a first person plural subject we, adverbs and locutions expressing probability ("probably", "there is no reason to expect"), and indirect forms of disapproval such as "wish to be altered".

The translator into Catalan has somewhat contracted the dialogic space by making his discourse more commanding (note the use of the first person) and by removing some of the hedges the character uses in the ST. Note, in particular, the rendering no permetré ('I shall not allow'), in which there is no space for opposition or change and the slightly more forceful translation no cal que pensem ('it is not necessary for us to think') for "there is no reason to expect". The translation is also more explicit in its evaluation: instead of using the paraphrase "much to wish altered", thus avoiding explicit negative evaluation, the Catalan molts defectes ('many defects') is blunter and more direct - and therefore less open to contradiction.

The figure who is assigned most direct speech in the first chapter is clearly Mrs. Norris, and on no less than three occasions she makes use of indeed.

In the following example her indeed gives emphasis to her recognition of Sir Thomas's high moral qualities - in Martin and White's terms: she proclaims or, to be more concrete, pronounces her view (Martin \& White 2005: 127) - but only to disclaim, more specifically to counter, in the larger context of her intervention, the validity of his arguments on this occasion (cf. Aijmer 2007: 337):

(9) ST I perfectly comprehend you, and do justice to the generosity and delicacy of your notions, which indeed are quite of a piece with your general conduct [...]. (Austen 4)

T1 [...] la generosidad y delicadeza de tus intenciones, que, en realidad, forman un solo cuerpo con tu norma general de conducta (Martín 11)

T2 [...] la generosidad y delicadeza de sus principios, que sin duda forman parte de su conducta general (Torres 10)

T3 la generositat i delicadesa de les vostres opinions, que evidentment concorden amb la vostra conducta en general (Ventós 11)

T4 [...] die Großzügigkeit und das Zartgefühl ihrer (sic) Empfindungen, die ja auch ganz Ihren sonstigen Einstellungen entsprechen [...]. (Grawe \& Grawe 9)

T5 [...] Ihre hochherzigen und feinsinnigen Erwägungen zu würdigen, die in der Tat ganz Ihrem sonstigen Verhalten entsprechen [...] (Meyer 8)

All the translations introduce some form of modalization. In der Tat and sin duda equal the effect of the original. En realidad is closer to in point of fact than to indeed and betrays a somewhat reluctant conceding concurrence (cf. Martin \& White 2005: 125). Evidentment affirms concurrence, between Mrs. Norris and those present, and possibly also other people who know Sir Thomas. The German modaliser (or Abtönungspartikel, to use the term coined by Weydt 1969) ja presents the information as shared and related with previous observations (Helbig 1990: 165). Like for other 'nuancing particles', its use is 
characteristic of authentic speech and personal, associative communication (Hentschel 1986: 243). Grawe and Grawe's Mrs. Norris even combines it with a second explanatory modal particle auch, which conveys a certain emotional involvement: the figure appears to adopt a more participative rhetoric - and the narrator of this version adds a flavour of fictive orality which is not present with equal force in the other translations.

In initial position indeed combines the functions of discourse marker and epistemic element; this function can be seen in example (10):

(10) ST Indeed, I do not see that you could possibly place her any where else. (Austen 7)

T1 Realmente, no veo en qué otro lugar podrías colocarla. (Martín 14)

T2 A decir verdad, no veo en dónde podrías alojarla, si no. (Torres 14)

T3 La veritat, no sé pas en quin altre lloc la podríeu col·locar. (Ventós 13)

T4 Ja, ich wüsste wirklich gar nicht [...] (Grawe \& Grawe 14)

T5 Ich wüsste wirklich nicht, wo [...]. (Meyer 13)

The adverb marks a pronouncement, but also that final remark of Mrs. Norris's demonstration with which she definitely imposes her 'suggestion' of organization on the lady of Mansfield Park. With slight variations, the translations reproduce the pronouncement quality.

In all cases, the character displays emotional involvement and opposition to contrary positions (White 2003: 269). A decir verdad sounds as if the speaker were sorry to pronounce this lack of alternatives, as does la veritat in the Catalan translation; on the other hand, the double marking Ja, ... wirklich transmits a particularly strong pronouncement. The weakest version is Meyer's wirklich in mid-sentence position; the other translations maintain the combination of discourse marker and epistemic element.

Mrs. Norris is profuse in tokens of engagement of all kinds: in this first chapter alone, she formulates three strong pronouncements with I am sure (and there is another instance in indirect speech: she was sure) and entertains her own standpoint with at least three I dare say. The narrator explicitly characterizes her through her love of talking, directing, dictating, and the analysis of her torrents of words, and especially their epistemic elements, when viewed through the grid of Martin and White's concept of engagement reveals her as an authoritarian, selfcentred and self-satisfied person.

\subsection{Indirect speech and free indirect speech}

Narrative report of speech acts such as we saw in 3.1 shares many traits with indirect speech. Indirect speech is formally characterised by the use of a reporting verb (construing the narrator perspective) with a sentential complement denoting a proposition. As a resource it is available for all categories across the spectrum of heteroglossic stance. The narrator as 
reporter is the internal subjectivity, while the character as the reportee is the external voice.

Free indirect speech presents the reader with a different configuration of voices. It is characterised by the absence of the reporting verb and the presence of linguistic features that might typify the language of a character or characters (see Fludernik 1993: 398-408). The passage will be perceived as a form of reported discourse only if the reader realizes that the narrator's phrasing might be a (partial) reproduction of one of the characters' wording. Since the forms of assimilation are as multi-faceted as the diversity of imaginable speech acts, Appraisal Theory has not yet been able to develop sufficient tools to detect them. ${ }^{11}$ Consider the following passage, with Sir Thomas's reaction to the proposal that the Bertrams adopt Fanny Price.

(11) ST Sir Thomas could not give so instantaneous and unqualified a consent. He debated and hesitated; - it was a serious charge; - a girl so brought up must be adequately provided for, or there would be cruelty instead of kindness in taking her from her family. He thought of his own four children of his two sons - of cousins in love, \&c [...] (Austen 4)

T3 Sir Thomas no podia donar un consentiment tan sobtat i irreflexiu. Va rumiar i va dubtar; era una responsabilitat molt gran.

-Cal acollir adequadament una nena d'aquesta edat; si no, seria una crueltat en lloc d'una gentilesa apartar-la de la seva família.

Va pensar en els seus quatre fills - en els seus dos nois -, en els enamoraments entre cosins, etcètera [...]. (Ventós 11)

T4 Sir Thomas konnte seine Zustimmung nicht so spontan und ohne weiteres geben. Er widersprach und zögerte. Es sei eine schwere Verantwortung, wenn man ein Mädchen aufziehe, müsse man auch später angemessen für sie sorgen, sonst wäre es Grausamkeit und nicht Freundlichkeit, sie ihrer Familie wegzunehmen. Er denke an seine eigenen vier Kinder, an seine beiden Söhne, an verliebte Vettern usw. (Grawe \& Grawe 8-9)

T5 Sir Thomas konnte nicht so unumwunden und vorbehaltlos seine Zustimmung geben. Er überlegte hin und her und zögerte. Es war eine ernste Verantwortung. Für ein Mädchen, das so aufwachsen würde, musste angemessen gesorgt werden, denn sonst wäre es grausam und nicht wohltätig, es von seiner Familie zu trennen. Er dachte an seine eigenen vier Kinder, an seine beiden Söhne, an verliebte Cousins und Cousinen und so weiter [...] (Meyer 8)

In the first sentence of the source text passage, the third person subject and the past tense allow for an ambivalence of point of view between the narrator and Sir Thomas. The narrator mediates in the second sentence ("He debated and hesitated"), but the arguments are provided in free indirect speech ("it was a

\footnotetext{
${ }^{11}$ See The Appraisal Website

http://www.grammatics.com/appraisal/appraisalguide/unframed/stage4-

intertextuality.htm
} 
serious charge", etc.). This alternation of explicit narratorial voice with narratormediated character voice can be interpreted in engagement terms as acknowledging the character's views. At the same time the reader is invited to either align or disalign with Sir Thomas's objections, whether uttered or thought. Nevertheless, the way Sir Thomas's thoughts and words are presented - the absence of hedges; the use of the deontic must, ambivalent in time reference; the aggregation of not fully formulated doubts and the fact that his opinions are consistent with his actions - pushes the reader to align with his considerations. In free indirect speech the reader is engaging with the narrator and the character at the same time.

The changes made in the speech presentation mode by the Catalan translator are interesting: only the sentence translating "it was a serious charge" - era una gran responsabilitat ('it was a great responsibility') - can be argued to maintain the free indirect speech or thought used in the original. The rest of Sir Thomas's voiced objections are given in direct speech mode. The result of this shift in mode is a loss of narratorial endorsement, a higher degree of neutrality towards this utterance on the part of the narrator.

While the original's preceding "debated" simply attests heteroglossic activity, Grawe and Grawe's translation ("Er widersprach und zögerte.") has the narrator acknowledge a straightforward act of disclaiming, a denial on the part of Sir Thomas, which presents him as somewhat more outspoken than the original's character. Konjunktiv I, the German mode of indirectness, which has no equivalent in English, puts the following remarks clearly as his reported speech. Meyer on the other hand adopts a verb of thought ("Er überlegte hin und her und zögerte" [Meyer 8]) instead of speech. Her text runs on in Indikativ, turning the following sentences into "erlebte Rede" (Duden 2006: 539-540) - though it is in this case rather 'experienced thought' than 'experienced speech' (Gallagher 2001: 220-222). The narrator appears all the more omniscient as evidence of mediation diminishes.

Instances where free indirect speech or thought has been rendered as other forms of speech and thought presentation (direct or indirect speech) have been observed in translation of narrative fiction from English into various Romance languages such as Catalan, Portuguese and Spanish (cf. Alsina 2008, 2011, Rosa 2009, Zaro 2006). Factors playing a role in this shift are, among others, interlinguistic differences, varying degrees of familiarity of the target readership with certain literary techniques and the tendency in translation to level out marked language.

Such changes may have narratological consequences such as point of view shift from character to narrator or vice versa (Alsina 2011: 16). This tendency can be seen both in the Catalan translation of example (11), where free indirect speech is changed into direct speech, and in the first Spanish translation of example (12), where it is changed into indirect speech. 
Absence of explicit narratorial mediation can be interpreted as distancing. Consider the following passage, where Sir Thomas and Lady Bertram find out that Mrs. Norris has no intention of taking Fanny with her:

(12) ST He [Sir Thomas] had been considering her [Fanny] as a particularly welcome addition at the Parsonage, as a desirable companion to an aunt who had no children of her own; but he found himself wholly mistaken. Mrs. Norris was sorry to say, that the little girl's staying with them, at least as things then were, was quite out of the question. (Austen 7)

T1 [...] La señora Norris afirmó que lamentaba tener que manifestar que, al menos tal como iban entonces las cosas, eso de quedarse ellos con la niña era algo que estaba fuera de toda discusión. (Martín 13)

[Mrs. Norris stated that she regretted having to say that, at least the way things were going then]

T2 [...] La señora Norris sentía decir que era impensable que la niña se quedase a vivir con ellos, al menos en la actual situación. (Torres 13)

[Mrs. Norris was sorry to say that it was unthinkable that the girl should go to live with them, at least in the current situation.]

The last sentence of the source text passage is in free indirect speech: the reader recognizes in the formulation "was sorry to say" an instance of her usual style, compatible with such self-endorsing formulae as "I dare say", "indeed" etc. On the preceding page the narrator has explicitly commented upon her insincerity and/or self-deceit/self-deception (Austen 6). Now she produces what sounds like Mrs. Norris's own words, not in the dramatic or semi-dramatic mode of direct or reported speech, as if the character had become alive in the scene in question, but presenting as narrative fact what both the reader and herself know to be most probably untrue. Pretending to take Mrs. Norris's words at face value, the narrator introduces an additional level of shared understanding between her reader and herself: a wink which addresses him a 'judge for yourself'. Being poked fun at, the character appears even more real and 'preexistent' to the narration, and on the behalf of the narrator, it is a distancing move which anticipates her disagreement with the contents to be presented by Mrs. Norris.

The Martín translation does not reproduce this particular point of mockery. With the insertion of the explicit verbum dicendi afirmó ('stated'), its narrator acknowledges her declaration of regret. The other characters' responses are also narrator-framed, and hence Mrs. Norris is on the same level of narrative structure as Lady Bertram ("said Lady Bertram with the utmost composure" [Austen 7]) and Sir Thomas ("After a short pause, Sir Thomas added with dignity [...]" [Austen 7]). The narrator voice is disassociated from the external source equally for all three characters. The simultaneous dialogic engagement with character and narrator which is constitutive of free indirect speech becomes sequential. 
But in Martín's translation, too, there is a tint of irony: three consecutively embedded verbs of speech with the repetition of the conjunction que in a line depict Mrs. Norris's volubility and arouse the reader's suspicion.

\section{Discussion and conclusions}

Martin and White's concept of engagement helps to pose questions on various aspects of the narrator's point of view (and indeed that of any character in the novel): to what extent does she believe in or give support to perceptions and evaluations? To what extent does she believe in or give support to sources? To what extent does she (pretend to) cooperate with the reader in the construction of attitudes?

In the first chapter of Mansfield Park the narrator either expresses her own views or else acts as a mediator of views of characters. When she is acting as a mediator, her most frequent engagement move is the attribution of characters' propositions. Apparently, the propositions are acknowledged since the verba dicendi are not explicitly distancing. However, distancing is more nuanced in a literary work than in non-fiction genres; in Mansfield Park it takes place on different levels, both linguistic and narratological, including the juxtaposition of voices and the portrayal of the characters behind them, and the expression of attitude and graduation.

The narrator lets the characters speak for themselves, forcing the reader to engage directly with them and their more or less expansive or contractive styles in conversation, regardless of the speech presentation mode used. An examination of the translations shows that this aspect of the characters' disposition can be significantly altered by the way their speech is rendered in the target language.

The narrator's lexicogrammatical tokens of engagement are so scarce and mold so naturally into discourse that applying Martin and White's 'grid' helps to detect the contrast between the narrator and some of the characters. Perhaps the clearest example is Mrs. Norris, who becomes so contractive and exorbitant in self-orchestration that the narrator appears all the more tempered and expansive. Since there are few manifestations of engagement on the narrator's part, their translation takes on a special importance.

Using Martin and White's typologies for a fine-grained semantic analysis of a sample of textual choices (and their proposed translation equivalents) reveals the full extent of their multidimensionality and potential narratological consequences.

The surprise element in exclaim and the hyperbolic judgment in attack confer on these lexical items the quality of "engagement-rich" points - in analogy with the "value-rich" points in Munday (2012: 41) - because they contribute to the ironical feel, the impression that the narrator is at the same time acknowledging propositions from other voices but distancing herself from them by projecting 
attitudinal values (affect and judgment). Something similar can be said about shifts in orientation, from ambivalent to positive. The effects of the loss of attitudinal components such as surprise and hyperbole, and of shifts in orientation, on the reception of the translated version may range from negligible - if they are local and sporadic - to far-reaching, if they are sustained, as they gradually undermine the message. T2 and T3 provide several examples of this. It would be necessary to study the whole novel to confirm the extent of the alteration.

In argumentative texts, which are the genres that Martin and White analyse, the writer is a pre-existing entity which either forms part of the reader's world or about which the reader can find information. In literature, except for autobiographical texts, the reader cannot align with a voice until s/he has constructed his/her perception of it as the text progresses. Apart from lexicogrammatical items, there are, for example, suprasegmental ones which come into play in this process. They may involve or reflect syntactic structuring, but for the time being Appraisal Theory does not yet offer the tools to detect them. Here, the comparison of translations can sharpen our perception: every translation represents an interpretation - or at least the closest possible approximation of the target language to that interpretation.

German punctuation, for example, which is bound to reflect syntactic structure and is less pause-oriented, is sometimes unable to reproduce the short intonation curves of the original and the subsequent tone of semi-improvised speech in its narratorial discourse (or at least it cannot do so within the standards of a neutral, normative use of the comma). Especially Grawe and Grawe (T4) balance this by introducing lexical elements which are typical of oral, cooperative speech.

As for the causes of shifts in translation, we have no evidence of any of the translators consciously imposing their subjectivities onto that of Jane Austen. Translators may have had a preconceived idea of a style suitable for Mansfield Park, more restrained and formal in T2 and T3, and more conversational in T4.

In points which are not yet accessible with today's tools of Appraisal Theory, the comparison between source text and translations permits the analyst to appreciate qualities of the original which are so natural that they might pass unnoticed. In a wider perspective the comparison of translations and their source can serve contrastive linguistics when it reveals differences between the corresponding linguistic systems.

\section{References}

Aijmer, Karin (2007). Modal Adverbs as Discourse Markers. Connectivity in Grammar and Discourse, eds. Jochen Rehbein, Christiane Hohenstein \& Lukas Pietsch. Amsterdam: John Benjamins, 329-344. 
Alsina, Victòria (2008). Llengua i estilística en la narrativa de Jane Austen. Les traduccions al català [Language and Stylistics in Jane Austen's Narrative. The Catalan Translations]. Vic: Eumo.

Alsina, Victòria (2011). Translating Free Indirect Discourse. Two Spanish Versions of Jane Austen's Persuasion, New Voices in Translation Studies 7, 1-18.

Alsina, Victòria (2012). The Translator's Style. Evaluation in Three Translations of Jane Austen's Persuasion. Iberian Studies on Translation and Interpreting, eds. Isabel García-Izquierdo \& Esther Monzó. Oxford/Bern, etc.: Peter Lang, 293-316.

Austen, Jane ([1970] 1988). Mansfield Park. Edited by James Kinsley \& John Lucas. The World's Classics Series. Oxford: Oxford University Press.

Austen, Jane (1990). Mansfield Park. Traducción de Maria Dolors Ventós. Barcelona: Club editor.

Austen, Jane (1995). Mansfield Park. Traducción de Miguel Martín Martín. Barcelona: Rialp.

Austen, Jane (1997). Mansfield Park. Traducción de Francisco Torres Oliver. Barcelona: Alba Editorial.

Austen, Jane ([1984] 2010). Mansfield Park. Aus dem Englischen übersetzt von Ursula und Christian Grawe. Nachwort und Anmerkungen von Christian Grawe. Stuttgart: Philipp Reclam jun.

Austen, Jane ([1989] 2010). Mansfield Park. Aus dem Englischen von Margit Meyer. Herausgegeben und mit einem Nachwort versehen von Klaus Udo Szudra. Berlin: Aufbau Verlag.

Babb, Howard, S. (1962). Jane Austen's Novels. The Fabric of Dialogue. Ohio: Ohio State University Press.

Bal, Mieke ([1985] 1997). Narratology. Introduction to the Theory of Narrative. Translated by C. van Boheemen. Toronto: University of Toronto Press.

Bednarek, Monika (2006). Evaluation in Media Discourse. Analysis of a Newspaper Corpus. London: Continuum.

Booth, Wayne (1961). The Rhetoric of Fiction. Chicago, IL: University of Chicago Press.

Bray, Joe (2014). Speech and Thought Presentation in Stylistics. The Routledge Handbook of Stylistics, ed. Michael Burke. London and New York: Routledge, 222236.

Cohn, Dorrit (1983). Transparent Minds. Narrative Modes for Presenting Consciousness in Fiction. Princeton, NJ: Princeton University Press.

Dixon, Peter \& Bortolussi, Marisa (2001). Prolegomena for a Science of Psychonarratology. New Perspectives on Narrative Perspective, eds. Willie van Peer \& Seymour Chatman. Albany: State University of New York Press, 275-287.

Duden (2006). Die Grammatik der deutschen Gegenwartssprache. Nach den Regeln der neuen deutschen Rechtschreibung 2006 überarbeiteter Neudruck der 7., völlig neu erarbeiteten und erweiterten Auflage. Mannheim, Leipzig, Wien and Zürich: Dudenverlag.

Espunya, Anna \& Pavić Pintarić, Anita (2016). Identität und Emotionalität in Vázquez Montalbáns Carvalho Roman Los mares del sur und seinen deutschen 
Übersetzungen. Sprachliche Konstituierung der Identität durch Emotionalität, eds. Anita Pavić Pintarić, Zaneta Sambunjak \& Tomislav Zelic. Tübingen: Gunter Narr, 127-143.

Farias de Souza, Ladjane Maria (2013). Interlingual Re-Instantiation. A New Systemic Functional Perspective on Translation, Text \& Talk 33(4-5), 575-594.

Fludernik, Monika (1993). The Fictions of Language and the Languages of Fiction. London: Routledge.

Fowler, Roger ([1986] 1996). Linguistic Criticism. Oxford: Oxford University Press.

Gallagher, John D. (2001). Le discours indirect libre vu par le traducteur. Oralité et traduction, ed. Michel Ballard. (Collection Traductologie). Arras: Artois Presses Université, 209-244.

Hatim, Basil \& Mason, lan (1990). Discourse and the Translator. Harlow: Longman.

Hatim, Basil \& Mason, Ian (1997). The Translator as Communicator. London: Routledge.

Helbig, Gerhard (1990). Lexikon deutscher Partikeln. 2., unveränderte Auflage. Leipzig: Verlag Enzyklopädie.

Hentschel, Elke (1986). Funktion und Geschichte deutscher Partikeln. ,ja', ,doch', ,halt' und ,eben'. (Reihe germanistische Linguistik 63). Tübingen: Niemeyer.

Hood, Susan (2010). Appraising Research. Evaluation in Academic Writing. London: Palgrave Macmillan.

Leech, Geoffrey \& Short, Michael H. ([1981] 2007). Style in Fiction. A Linguistic Introduction to English Fictional Prose. London and New York: Longman.

Lodge, David (1966). The Language of Fiction. London: Routledge and Kegan Paul.

Macken-Horarik, Mary (2003). Appraisal and the Special Instructiveness of Narrative, Text 23(2), 285-312.

Margolin, Uri (2014). Narrator. The Living Handbook of Narratology. Available at: http://www.Ihn.uni-hamburg.de/article/narrator (accessed 15 January 2016).

Martin, James Robert \& White, Peter R. R. (2005). The Language of Evaluation. Appraisal in English. Houndmills and New York: Palgrave Macmillan.

McHale, Brian (1978). Free Indirect Discourse. A Survey of Recent Accounts, PTL, A Journal for Descriptive Poetics and Theory of Literature 3, 249-78.

McHale, Brian ([2011] 2014). Speech Representation. The Living Handbook of Narratology. Available at: http://www.Ihn.uni-hamburg.de/article/speechrepresentation (accessed 16 November 2016).

Miller, Donna R. \& Luporini, Antonella (2015). Social Semiotic Stylistics and the Corpus - Step 2: Appraising tru* in J.M. Coetzee's Foe. Paper presented at the International Systemic Functional Conference 2015 "Challenging Boundaries", Aachen July 2731.

Morini, Massimiliano (2010). The Poetics of Disengagement. Jane Austen and Echoic Irony, Language and Literature 19(4), 339-356.

Munday, Jeremy (2012). Evaluation in Translation. Critical Points of Translator DecisionMaking. London: Routledge. 
Niederhoff, Burkhard (2013). Perspective - Point of View. The Living Handbook of Narratology. Available at: http://www.Ihn.uni-hamburg.de/article/ perspective--point-view (accessed 22 January 2016).

Nünning, Ansgar (2001). On the Perspective Structure of Narrative Texts. New Perspectives on Narrative Perspective, eds. Willie van Peer \& Seymour Benjamin Chatman. Albany: State University of New York Press, 207-223.

Peng, Xuanwei (2008). Evaluative Meanings in Literary Texts. The First Step Towards Appraisal Stylistics. Systemic Functional Linguistics in Use. Odense Working Papers in Language and Communication 29. Ed. Nina Nørgaard, 665-684.

Poovey, Mary (1997). The True English Style. Mansfield Park and Persuasion, ed. Judy Simons. Houndmills, Basinstoke and New York: Palgrave, 93-106.

Rosa, Alexandra Assis (2009). Narrator Profile in Translation. Work-in-Progress for a Semi-Automatic Analysis of Narratorial Profile and Attitudinal Positioning in Translated Fiction. Manuscript. University of Lisbon.

Stockwell, Peter (2009). Texture. A Cognitive Aesthetics of Reading. Edinburgh: Edinburgh University Press.

Stockwell, Peter (2013). The Positioned Reader, Language and Literature 22(3), 263277.

Stovel, Bruce (1997). Further Reading. The Cambridge Companion to Jane Austen, eds. Edward Copeland \& Juliet McMaster. Cambridge: Cambridge University Press, 227-243.

Toolan, Michael J. (2001). Narrative. A Critical Linguistic Introduction. London and New York: Routledge.

Wales, Katie (2001). A Dictionary of Stylistics. London: Longman. 2nd ed.

Weydt, Harald (1969). Abtönungspartikel. Die deutschen Modalwörter und ihre französischen Entsprechungen. Bad Homburg, Berlin and Zürich: Gehlen.

White, Peter (2003). Beyond Modality and Hedging. A Dialogic View of the Language of Intersubjective Stance, Text 23(2), 259-284.

Yallop, Colin (2001). The Construction of Equivalence. Exploring Translation and Multilingual Text Production. Beyond Content, eds. Erich Steiner \& Colin Yallop. Berlin and New York: Mouton de Gruyter, 229-246.

Zaro, Juan Jesús (2006). Problemas de traducción del estilo indirecto libre en la novela inglesa clásica. Gramática y traducción, eds. Pilar Elena \& Josse de Kock. Salamanca: Ediciones Universidad de Salamanca, 279-300.

Øverås, Lynn (1998). In Search of the Third Code. An Investigation of Norms in Literary Translation, Meta 43(4), 557-570.

\section{Electronic dictionary entries}

Digitales Wörterbuch der deutschen Sprache. URL address: http://www.dwds.de/

Duden online. URL address: http://www.duden.de/

OED Online. Oxford University Press.

The Appraisal website: 
http://www.grammatics.com/appraisal/appraisalguide/unframed/stage4intertextuality.htm 